\title{
INTERNALISASI NILAI - NILAI MULTIKULTURALISME MELALUI KULTUR SEKOLAH
}

Oleh:

Ghufronudin ${ }^{1}$

\begin{abstract}
Abstrak
Dinamika globalisasi dan kemajuan teknologi informasi turut memberikan ekses bagi meningkatnya sikap dan perilaku intoleransi. Penelitian ini bertujuan untuk mengetahui bagaimana peran kultur sekolah dalam proses internalisasi nilai-nilai multikulturalisme di sekolah. Penelitian kualitatif dengan pendekatan studi kasus ini dilaksanakan di SMA Warga Surakarta dengan informan yang dipilih dengan model purposive sampling. Teknik pengumpulan data dengan observasi, wawancara mendalam dan dokumentasi. Validitas data dengan triangulasi sumber, kemudian dianalisis dengan model interaktif. Hasil penelitian menunjukkan bahwa internalisasi nilai-nilai multikulturalisme terbentuk melalui beberapa aspek kultur sekolah seperti 1) nilai-nilai moral, sistem peraturan, dan iklim kehidupan sekolah; 2) Civitas akademika sekolah yang terdiri atas siswa, guru, dan karyawan; 3) Kurikulum sekolah yang memuat gagasan maupun fakta yang menjadi keseluruhan program pendidikan serta 4) Letak, lingkungan, dan prasarana fisik sekolah meliputi gedung sekolah, mebelair, dan perlengkapan lainnya.
\end{abstract}

Kata Kunci: Internalisasi, Kultur Sekolah, Multikulturalisme

\footnotetext{
${ }^{1}$ Program Studi Pendidikan Sosiologi Antropologi, Fakultas Keguruan dan Ilmu Pendidikan, Universitas Sebelas Maret. Email: ghufron.udin@staff.uns.ac.id
} 


\section{Pendahuluan}

Sebagai negara yang majemuk, Indonesia memiliki keanekaragaman suku, ras, adat istiadat, etnis, maupun agama. Pluralitas ini menjadi potensi kekayaan atau keistimewaan bagi bangsa Indonesia manakala di dalamnya tercipta suatu masyarakat harmonis yang termanifestasi dengan adanya relasi saling menghargai perbedaan satu sama lain. Isu mengenai toleransi seharusnya menjadi salah satu isu utama yang diperhatikan oleh masyarakat dan pemerintah. Hal ini penting dilakukan mengingat telah banyak pihak sudah menyoroti munculnya kelompokkelompok intoleran berbasis etnis atau agama yang berani bertindak diskriminatif dan bahkan melakukan perilaku kekerasan yang sudah terjadi di beberapa kasus.

Berdasarkan hasil survei yang dilakukan Komisi Nasional Hak Asasi Manusia (Komnas HAM) bekerjasama dengan Litbang Kompas pada medio 25 September sampai 5 Oktober 2018 mengindikasikan betapa masih canggungnya masyarakat Indonesia menerima keragaman etnis dan ras.
Kendati semboyan Bhinneka Tunggal Ika kerap di gemborkan dalam kehidupan sosial dan bahkan di ranah diplomasi. Berdasarkan survei tersebut ditemukan data bahwa sebanyak $81,9 \%$ responden mengatakan lebih nyaman hidup dalam keturunan keluarga yang sama. Kemudian, sebanyak 82,7\% responden mengatakan bahwa mereka lebih nyaman hidup dalam lingkungan ras yang sama. Sementara sebanyak 83,1 \% mengatakan lebih nyaman hidup dengan kelompok etnis yang sama.

Lebih lanjut Komnas HAM mencatat sedikitnya 101 kasus diskriminasi ras dan etnis dalam periode 2011-2018 yang dilaporkan kepada mereka. Pelanggaran tersebut meliputi pembatasan terhadap pelayanan publik, maraknya politik etnisitas atau identitas, pembubaran ritual adat, diskriminasi atas hak kepemilikan tanah bagi kelompok minoritas, serta akses ketenagakerjaan yang belum berkeadilan. Secara kualitatif survei tersebut mengindikasikan bahwa tingkat segregasi sosial di masyarakat masih tinggi. Sehingga hal ini menyebabkan rasa penerimaan masyarakat akan realitas keberagaman 
masih jauh diwujudkan.

Sektor pendidikan diharapkan menjadi sarana

bagi penumbuhkembangan budaya toleransi keberagaman bagi siswa. Namun riset Akenson (2004) berpandangan bahwa sistem pendidikan merupakan salah satu struktur institusi utama yang melanggengkan intoleransi sektarian. Melalui sektor pendidikan inilah toleransi dan intoleransi direproduksi sebagai sebuah siklus ilmu pengetahuan dan menjadi konstruksi sosial berkelanjutan.

Sektor pendidikan menjadi semakin rentan ketika kebijakan pendidikan tidak kondusif bagi pemajuan toleransi. Kurikulum, model pembelajaran, kualitas guru, standar evaluasi, dan banyak entitas pendidikan lainnya yang memungkinkan intoleransi terjadi. Lebih lanjut menurut Lisyarti (2015) menunjukkan bahwa penghargaan terhadap keberagaman di sekolahsekolah di Jakarta semakin menipis. Penolakan kegiatan keagamaan agama tertentu oleh kelompok yang dominan bukan hanya menjangkiti para siswa tapi juga diprakarsai oleh guru dan beberapa kepala sekolah.

Bertolak dari data di atas, pendidikan multikultural mutlak diperlukan bagi masa depan pendidikan Indonesia. Pendidikan multikultural perlu diberikan pada setiap jenjang pendidikan dari pendidikan dasar hingga pendidikan tinggi. Oleh karena itu dibutuhkan kultur sekolah yang bisa mendukung terwujudnya pendidikan multikultural secara baik dan kondusif.

Pemikiran dan praktik mengenai bagaimana implementasi pendidikan multikultural inilah yang akan menjadi fokus dalam penelitian ini. SMA Warga Surakarta merupakan satu-satunya sekolah pembauran yang ada di wilayah Suraarta. Sekolah ini merupakan salah satu unit sekolah yang berada di bawah Yayasan Warga Surakarta yang notabene merupakan sekolah percontohan pluralitas bagi masyarakat. Meskipun pendiri sekolah merupakan etnis Tionghoa yang beragama non islam, namun sekolah ini sangat inklusif dan toleran. Terlihat dari beragamnya komposisi agama maupun suku dari civitas akademiknya.

Melalui riset ini peneliti bertujuan 
untuk mengidentifikasi proses internalisasi nilai-nilai multikulturalisme melalui kultur sekolah yang menjadi dasar bagi tumbuhnya budaya toleransi keberagaman dari para siswa, guru dan juga karyawan SMA Warga Surakarta.

\section{Konsep Multikulturalisme}

Menurut Suparlan (2002) konsep multikulturalisme tidaklah dapat disamakan dengan konsep kemajemukan secara suku bangsa atau kebudayaan suku bangsa yang menjadi ciri masyarakat majemuk, karena konsep multikulturalisme menekankan pada adanya pengakuan keanekaragaman kebudayaan dalam kesederajatan. Lebih lanjut Suparlan menjelaskan bahwa multikulturalisme bukan hanya sebuah wacana, melainkan sebuah ideologi yang harus diperjuangkan karena dibutuhkan sebagai landasan bagi tegaknya demokrasi, HAM, dan kesejahteraan hidup masyarakatnya.

Menurut Parekh (2001) ada tiga komponen multikulturalisme yakni kebudayaan, pluralitas kebudayaan, dan cara tertentu untuk merespons pluralitas itu. Multikulturalisme bukanlah doktrin politik pragmatik, melainkan cara pandang kehidupan manusia. Karena hamper semua negara di dunia tersusun dari aneka ragam kebudayaan artinya perbedaan menjadi asasnya dan gerakan manusia dari satu tempat ke tempat lain di muka bumi semakin intensif, maka multikulturalisme itu harus diterjemahkan ke dalam kebijakan multikultural sebagai politik pengelolaan perbedaan kebudayaan warga negara.

Dari beberapa pendapat ahli tersebut dapat disimpulkan bahwa multikulturalisme merupakan sebuah paham atau ideologi yang mengajarkan tentang suatu sikap dan pandangan hidup yang menjunjung tinggi nilai-nilai toleransi atas keberagaman serta menempatkannya pada posisi yang sederajat.

\section{Kultur Sekolah}

Sebagai institusi pendidikan, sekolah memiliki peranan penting dalam membentuk sumber daya manusia unggul bagi terwujudnya cita-cita dan kemajuan suatu bangsa. Dalam rangka mencapai tujuan pendidikan tersebut, sekolah harus memiliki kultur sekolah yang 
mendukung. Menurut Deal and Peterson yang dalam (Efianingrum, 2013) sekolah berperan untuk mentransfer kebudayaan dari generasi ke generasi yang tentunya harus memperhatikan kondisi masyarakat dan kebudayaan umum. Karena kebudayaan yang berkembang di sekolah memiliki pola perilaku tertentu dan merupakan bagian dari masyarakat luas yang memiliki ciri khas sebagai subkebudayaan.

Peterson dalam Efianingrum (2012) mendefinisikan kultur sekolah sebagai sebuah jaringan bersifat kompleks pada tradisi dan ritual yang telah berkembang dari waktu ke waktu oleh guru, siswa, orang tua dan administrator yang berkinerja untuk menangani krisis prestasi. Dengan demikian perkembangan budaya sekolah tidak berlangsung singkat, akan tetapi merupakan perjalanan yang panjang yang terus diyakini dari masa ke masa oleh seluruh warga sekolah.

Hoy, Tarter, dan Kottkamp dalam Hanum (2013) mendefinisikan kultur sekolah sebagai sebuah sistem orientasi bersama (norma-norma, nilai-nilai, asumsi-asumsi dasar) yang di pegang oleh seluruh anggota sekolah, yang menjaga keeratan unit dan memberikan identitas yang berbeda. Budaya (culture) dapat menjadi ciri khas dari suatu sekolah yang menjadi identitas yang melekat berdasarkan nilai, keyakinan, serta asumsi yang berkembang didalam sekolah. Budaya sekolah atau kultur sekolah berkembang dari waktu ke waktu sebagai pengalaman atas cerminan perilaku dan menjadi karakteritik dari suatu sekolah. Sedangkan menurut Peterson (2002) suatu budaya sekolah mempengaruhi cara orang berpikir, merasa, dan bertindak. Mampu memahami dan membentuk budaya adalah kunci keberhasilan sekolah dalam mempromosikan staf dan belajar siswa.

Dari beberapa pendapat ahli tersebut dapat disimpulkan bahwa kultur sekolah dalam hal ini adalah sebuah sistem keyakinan, nilai-nilai serta asumsi yang di percaya bersama seluruh warga sekolah yang dapat menjadi ciri khas sekolah dan memiliki fungsi sebagai sebagai cara pemecahan masalah yang dianggap benar dan diwariskan dari generasi ke generasi. Melalui kultur sekolah akan menjadi stimulus yang 
mempengaruhi cara berpikir, merasa dan bertindak bagi keseluruhan warga sekolah.

Fokus dari kultur sekolah dalam penelitian ini adalah lebih kepada kultur sekolah yang mendukung tercipta dan tumbuhnya sikap dan perilaku toleransi dilandasi nilai-nilai multikulturalisme pada seluruh warga SMA Warga Surakarta.

\section{Metode Penelitian}

Penelitian kualitatif ini dilakukan di SMA Warga Surakarta dengan pendekatan studi kasus (Yin, 2014) dan pengambilan sampel secara purposive. Alasan pemilihan lokasi penelitian yakni karena SMA Warga Surakarta sebagai satu-satunya sekolah menengah atas swasta tertua di Surakarta yang menjadi pilot project sekolah pembauran pertama yang mengajarkan toleransi dan keberagaman. Unit analisis penelitian adalah stakeholders yang terdiri dari kepala sekolah, guru, karyawan dan siswa. Teknik pengumpulan data dengan observasi, wawancara mendalam dan studi pustaka. Validitas data menggunakan triangulasi sumber dan analisis data dengan analisis model interaktif (Milles dan Huberman, 1984).

\section{Hasil dan Pembahasan}

Deskripsi hasil penelitian dalam studi ini mendeskripsikan beberapa aspek kultur sekolah yang bersifat abstrak hingga konkret yang memiliki pengaruh terhadap tumbuhnya nilai-nilai multikulturalisme di civitas akademik SMA Warga Surakarta.

\section{Nilai-Nilai Moral, Sistem Peraturan dan Iklim Kehidupan Sekolah}

SMA Warga Surakarta sebagai salah satu institusi pendidikan di bawah naungan Yayasan Warga Surakarta berdiri pada tanggal 30 November 1904. Pendiri Yayasan Pendidikan Warga Surakarta adalah alm. Mayor Be Kwat Koen. Sementara itu, SMA Warga Surakarta berdiri pada tanggal 23 Mei 1960 yang dipimpin oleh Bapak Lo Hwan Hoei yang sekaligus menjabat Kepala Sekolah SLTP Warga Surakarta.

Sebagai tindak lanjut dari kebijakan pemerintah waktu itu, maka SMA Warga mengemban tugas sebagai sekolah pembauran. Sekolah pembauran 
SMA Warga Surakarta menjadi tonggak pendidikan yang mengedepankan pentingnya hidup bersama di antara komunitas yang berbeda etnis dan agama dengan mengajarkan nilai-nilai yang menekankan pada cinta kasih, toleransi dan keberagaman. SMA Warga Surakarta atau disebut juga dengan 'Sekolah Pembauran' menjadikan sekolah sebagai miniatur masyarakat dengan penuh aneka warna budaya.

Dalam konteks pendidikan multikultural, adanya sistem nilai dan norma berperan penting dalam menciptakan iklim kehidupan sekolah yang kondusif bagi keberagaman. SMA Warga Surakarta memiliki visi dan misi sebagai representasi nilai moral, sistem peraturan dan iklim kehidupan sekolah. Adapun visi SMA Warga yaitu mendidik siswa beriman, berbudaya, berprestasi, berjiwa wirausaha berbasis holistik, cinta lingkungan dan berwawasan global. Sedangkan misinya meliputi: 1) Menumbuhkan pengalaman iman dan kasih; 2) Membentuk siswa yang santun dan beretika; 3) Menghasilkan siswa yang berprestasi; 4) Membentuk siswa yang mampu berwirausaha; 5)
Menyediakan sistem pendidikan holistik dan berwawasan global serta 6) Menanamkan kepada seluruh civitas akademika mencintai lingkungan.

Perwujudan visi dan misi sekolah dalam kehidupan sehari-hari yang telah dipahami seganap civitas akaedemik sekolah telah menjadikan kultur sekolah SMA Warga Surakarta menjadi kultur yang ramah bagi kondisi keberagaman. Hal ini sejalan dengan pendapat Stolp dan Smith dalam Hanum (2013) bahwa kultur sekolah adalah pola makna yang didalamnya terdiri dari norma-norma, nilai-nilai, kepercayaan, tradisi dan mitos yang dipahami oleh setiap anggota komunitas sekolah.

Internalisasi adalah suatu pemahaman atau penafsiran individu secara langsung atas peristiwa objektif sebagai pengungkapan makna. Berger dan Luckmann (1990) dalam Manuaba (2008) menyatakan dalam internalisasi, individu mengidentifikasikan diri dengan berbagai lembaga sosial atau organisasi sosial di mana individu menjadi anggotanya. Berdasarkan hasil observasi penelitian, perwujudan visi dan misi sekolah terlihat sudah terlaksana dengan 
baik. Civitas akademika sekolah baik guru, karyawan maupun siswa mengidentifikasi diri dengan visi misi sekolah sebagai bentuk internalisasi. Hal ini terlihat dari upaya sekolah dalam mewujudkan kondusifitas iklim budaya sekolah yang mendukung jalannya proses belajar pembelajaran. Sekolah sangat menekankan pada kedisiplinan baik siswa, guru maupun karyawan. Khususnya pada siswa, setiap detail aktivitas siswa telah diatur oleh sistem peraturan sekolah yang mewajibkan mereka untuk menaatinya. Implementasi kedisiplinan tidak hanya diterapkan pada siswa, melainkan pada guru dan karyawan juga diberlakukan hal yang sama terutama disiplin waktu.

Terlepas dari aturan yang bersifat normatif, pihak sekolah juga menerapkan sistem nilai yang menghargai toleransi dan cinta kasih pada sesama. Perilaku toleransi diwujudkan dalam beberapa aspek dalam relasi sosial. Semisal di kelas, mekanisme berdoa dipimpin secara bergilir dari beberapa agama yang ada di kelas yang bersangkutan, ketika ada teman yang sedang mengalami lelayu (baik guru atau siswa) semua berempati dengan mengumpulkan dana tali asih dan melayat secara bersama. Pihak sekolah memfasilitasi kerohanian siswa melalui kelompok oganisasi seperti kerohanian islam, kristen, katholik, hindu, budha dan khonghucu. Sehingga siswa dapat bereksplorasi melakukan kegiatan keagamaan secara lebih maksimal.

Internalisasi merupakan peresapan kembali realitas oleh manusia dan mentransformasikannya kembali dari struktur struktur dunia objektif ke dalam struktur struktur kesadaran subjektif (Berger, 1994) dalam Manuaba (2008). Struktur objektif berupa sistem nilai-nilai multikulturalisme terinternalisasi pada diri subjektif senegap civitas akademika sekolah. Manifestasinya dalam bentuk rasa empati dan toleransi sudah mewarnai iklim kehidupan sekolah. Bahkan pada dua tahun terakhir ini pihak sekolah sudah mengizinkan guru, karyawan dan siswa muslim untuk mengenakan hijab. Kebijakan ini lantas memberikan dampak yang signifikan bagi sekolah karena meningkatnya respon masyarakat untuk menyekolahkan anaknya di sekolah ini. Maksud dari 
pihak sekolah mengeluarkan kebijakan ini adalah untuk lebih inklusif dan memberikan kebebasan beragama susuai keyakinan masing-masing. Selain melalui kegiatan pembelajaran di sekolah, internaslisasi nilai-nilai multikulturalisme juga dilakukan pihak sekolah dengan mengadakan kegiatan field trip setiap tahun sekali bagi semua siswa dengan mengunjungi semua tempat ibadah yang ada di beberapa kota besar.

Spirit nilai-nilai multikulturalisme tidak hanya terimplementasi pada ranah perbedaan agama saja melainkan juga pada perbeadaan budaya masing-masing etnis. Pihak sekolah memberikan pembelajaran wajib seni budaya kepada semua siswa. Dalam pembelajaran seni budaya ini siswa diajarkan mengenai keragaman budaya bangsa melalui kegiatan berkesenian. Pada saat sekolah atau luar sekolah (pemerintah atau swasta) mengadakan acara, siswa sering diminta untuk menampilakan berbagai tari tradisional daerah. Ditambah pada saat momen tertentu semisal peringatan hari kartini, sumpah pemuda maupun ulang tahun sekolah, semua civitas akademik sekolah diminta untuk mengenakan pakaian adat daerah.

Adanya representasi nilai-nilai multikulturalisme dalam iklim kehidupan sekolah menjadikan kultur keberagaman SMA Warga Surakarta sebagai ciri khas yang dapat menjadi identitas serta citra suatu lembaga pendidikan. Dalam fungsi dan peran kultur sekolah ini dapat menjadi ciri tersendiri dari suatu sekolah yang menjdi ciri khas dan membedakan antara sekolah satu dengan yang lainnya sesuai dengan kultur yang berkembang didalam sekolah.Sehingga hal ini dapat digunakan sebagai strategi bagi pihak sekolah dalam melakukan branding popularitas sekolah kepada masyarakat luas.

\section{Civitas Akademika Sekolah}

Sebagai institusi pendidikan formal, meskipun pendiri sekolah adalah sekelompok Tionghoa, namun sekolah tidak membatasi hanya agama dan etnis tertentu saja yang mendapatkan layanan pendidikan. Civitas akademika SMA Warga yang terdiri dari siswa, guru dan karyawan jika dilihat dari latar belakang sosial seperti agama maupun suku 
terbukti sangatlah plural. Karakteristik pluralitasnya meliputi agama maupun sukunya. Komposisi agama yang dianut civitas akademikanya meliputi agama islam, kristen, katholik, hindu, budha dan khonghucu. Sedangkan pluralitas suku meliputi suku Jawa, Bali, Manado, Batak dan lainnya. Untuk saat ini SMA Warga Surakarta memiliki siswa sebanyak 450 siswa dengan lima rombel di setiap tingkatnya. Sementara guru berjumlah 40, tenaga kependidikan berjumlah delapan dan karyawan berjumlah enam.

Civitas akademika sekolah yang terdiri dari guru dan karyawan sebagai agen sosialisasi sekunder memainkan peranan penting dalam proses internalisasi nilai-nilai multikulturalisme pada siswa. Berger dan Luckmann (1990) dalam Manuaba (2008) menegaskan bahwa sosialisasi sekunder adalah sosialisasi sejumlah "subdunia" kelembagaan, atau yang berlandaskan lembaga. Lingkup jangkauan dan sifat sosialisasi ini, ditentukan oleh kompleksitas pembagian kerja dan distribusi pengetahuan dalam masyarakat yang menyertainya. Sosialisasi sekunder adalah proses memperoleh pengetahuan khusus sesuai dengan peranannya (role specifc knowledge), dan peranan ditentukan berdasarkan pembagian kerja. Dalam berbagai kesempatan, sekolah melakukan internalisasi nilai-nilai multikulturalisme sebagai pengetahuan menganai relasi sosial dalam konteks keberagaman.

Konsensus akan nilai multikulralisme telah menjadi satu kesatuan dalam kehidupan sekolah. Meskipun kondisinya plural, relasi sosial yang terbangun dalam civitas akademika sekolah berjalan dengan harmonis. Hal ini sejalan dengan pendapat Deal dan Peterson (1999) dalam Hanum (2008) bahwa kultur sekolah mempengaruhi hubungan antarsesama sekolah dan segala aktivitas yang bersifat kolaboratif yang berpengaruh pada komunikasi yang lebih baik. Dalam relasi antar siswa, sikap toleransi terlihat sudah baik. Sesama siswa terbiasa untuk bertoleransi terhadap perilaku ibadah yang dilakukan masing-masing. Semisal ketika sedang berpuasa di bulan ramadhan, siswa yang beragama non muslim secara otomatis menghargai teman mereka yang muslim dengan tidak makan atau secara sengaja 
di depan mereka yang muslim. Selain itu ketika musim mudik lebaran, siswa yang beragama non muslim saling bekerja sama membantu memfasilitasi para pemudik dengan ikut mendirikan stand rest area. Tradisi buka bersama, bagi takjil, halal bi halal serta penyembelihan hewan qurban juga menjadi sarana bagi siswa, guru dan karyawan non muslim untuk membaur menjalin keakraban dan berpartisipasi menyemarakkan ibadah civitas akademika muslim. Relasi seperti ini juga berlaku ketika umat agama lain merayakan hari besar keagamaannya. Antara siswa muslim dengan siswa non muslim yang sedang merayakan, meraka turut membantu suksesnya acara di sekolah.

Internalisasi nilai dan norma juga terus diupayakan pihak sekolah melalui guru dan karyawan. Mereka banyak dilibatkan dalam acara kebersamaan dari beberapa peringatan hari besar masingmasing agama. Saling mengucapkan satu sama lain ketika memperingati hari besar keagaaman baik melalui komunikasi langsung maupun melalui media sosial menjadi habituasi yang sudah melakat. Dari sinilah muncul rasa saling toleransi dan mengasihi satu sama lain. Bahkan di luar sekolah, ketika mereka memiliki acara di rumah (semisal peringatan kematian) meskipun berbeda agama, guru dan karyawan lain tetap diundang untuk hadir. Selain itu, pihak sekolah juga rutin memberikan bingkisan kepada semua guru dan kayawan tanpa membedakan agama pada saat hari besar keagaaman. Adanya mekanisme perilaku seperti ini menjadi penanda bahwa kultur keberagaman sekolah telah menjadi pedoman bagi warga sekolah dalam batasan berprilaku yang sudah disepakati dan diwariskan secara bergenerasi dari waktu ke waktu.

\section{Kurikulum Sekolah}

SMA Warga Surakarta menerapkan kurikulum 2013 dalam proses belajar pembelajarannya. Dalam mendukung proses internalisasi nilainilai multikulturalisme, sekolah menjalankan program pengajaran yang masuk dalam muatan pembelajaram intrakurikuler dan ekstrakurikuler. Kegiatan ekstrakurikuler diberikan 
diberikan kepada siswa dengan tujuan memberikan pendidikan skill, moral atau karakter yang bermanfaat bagi masa depan siswa. Beberapa alasan pihak sekolah memberikan kegiatan ekstrakurikuler yaitu menjadikan peserta didik aktif, mengajarkan kerja sama tim, menyalurkan energi dan kreativitas, mengurangi risiko stres dan mengajarkan siswa untuk belajar manajemen waktu. Melalui kegiatan intrakurikuler maupun ekstrakurikuler, siswa belajar implementasi nilai multiukulturalisme seperti toleransi, tenggangrasa, saling menghargai dan belajar mengendalikan ego pribadi.

Berbagai kegiatan ekstrakurikuler yang difasilitasi sekolah meliputi pramuka, futsal, jurnalistik, marching band, PMR, paduan suara, pasukan inti (PBB), karya ilmiah remaja, seni tari tradisional, seni tari modern, karate, band pelajar, bulu tangkis, bola basket dan esport. Dalam proses berkegiatan, mereka terlibat proses interaksi satu sama lain yang memunculkan rasa kerjasama, simpati, peduli dan kerja tim satu sama lain. Sehingga berbagai kegiatan sekolah yang diupayakan pihak sekolah tersebut secara tidak langsung menjadi agen bagi proses internalisasi nilai-nilai multikulturalisme bagi siswa.

\section{Letak, Lingkungan dan Prasarana} Fisik Sekolah

SMA Warga Surakarta terletak di tengah Kota Surakarta. Akses lokasi menuju sekolah ini sangatlah mudah dijangkau baik melalui transportasi umum maupun pribadi. Sekolah ini beralalamatkan di Jalan Monginsidi 17, Kelurahan Tegalharjo, Kecamatan Jebres, Surakarta, Jawa Tengah. Berbagai sarana fisik yang dimiliki sekolah sudah terlihat memadai dalam mendukung terciptanya kultur sekolah yang kondusif bagi berjalannya kegiatan belajar pembelajaran. Adapun berbagai sarana fisik yang dimiliki sekolah meliputi semua ruang kelas ber $\mathrm{AC}$ dan LCD proyektor, tempat ibadah berbagai agama, lapangan basket (indoor), lapangan bulu tangkis (indoor), lapangan voli, lapangan futsal (indoor), parkir motor, studio musik, hotspot area (6 titik), perpustakaan dengan sistem digital, laboratorium multimedia, laboratorium komputer, laboratorium 
bahasa, laboratorium biologi, dapat dilihat dari temuan data penelitian laboratorium kimia, laboratorium fisika, dalam beberapa aspek seperti 1) nilaiaula, lapangan upacara dan kantin. nilai moral, sistem peraturan, dan iklim Berbagai sarana prasarana yang dimiliki kehidupan sekolah; 2) Civitas akademika sekolah sebagai artifak kebudayaan berperan penting dalam menjadikan proses pembentukan kultur sekolah terkait dengan internalisasi nilai-nilai multikulturalisme menjadi lebih mudah untuk dicapai.

\section{Kesimpulan}

Berdasarkan hasil penelitian serta pembahasan dan temuan penelitian yang telah dilakukan maka dapat diambil kesimpulan bahwa kultur keberagaman SMA Warga Surakarta dalam proses internalisasi nilai-nilai multikulturalisme telah berjalan cukup optimal. Hal ini sekolah yang terdiri atas siswa, guru, dan karyawan; 3) Kurikulum sekolah yang memuat gagasan maupun fakta yang menjadi keseluruhan program pendidikan serta 4) Letak, lingkungan, dan prasarana fisik sekolah meliputi gedung sekolah, mebelair, dan perlengkapan lainnya. Nilai-nilai seperti toleransi, kebersamaan dan rasa solidaritas merupakan nilai yang sangat kuat berkembang baik antara siswa maupun guru dan karyawan. Nilai dan keyakinan yang terdapat di sekolah masih membutuhkan komitmen dan upaya terus menerus agar kultur positif seperti ini dapat terus dikembangkan secara optimal.

\section{Daftar Pustaka}

Akenson, Donald, Intolerance, the Ecoli of the Mind, Canberra: Humanities Research Centre, Australian National University, 2004.

Efianingrum, Ariefa. 2012. Kultur Sekolah. Jurnal Pemikiran Sosiologi Fisipol Vol. 2 No. 1, Mei. Universitas Gadjah Mada

Hanum, Farida. 2008. Studi Tentang Kultur Sekolah pada Sekolah Nasional Berstandar Internasional dan Sekolah Bermutu Kurang di Kota Yogyakarta. Laporan Penelitian. Universitas Negeri Yogyakarta.

Hanum, Farida. 2013. Sosiologi Pendidikan.Yogyakarta: Kanwa Publisher. 
https://tirto.id/survei-komnas-ham-diskriminasi-etnis-ras-masih-terus-ditolerir

Listiyarti, Retno, FSGI Jakarta. Pendapat tersebut disampaikan pada acara Workshop Penulisan Modul Pendidikan Toleransi yang diselenggarakan oleh SETARA Institute pada tanggal 20 Januari 2015 di Jakarta.

Manuaba, Putra I.B. 2008. Masyarakat, Kebudayaan dan Politik,. Jurnal. Th. XXI. No. 3, Juli-September 2008, 221-230

Miles, M. B and Huberman, A. M .1984. Qualitative Data Analysis: A Sourcebook of NewMethods. Michigan University: Sage Publications.

Parekh, Bikhu. 2001. Rethinking Multiculturalism. Harvard.

Peterson, Kent. D. 2002. Positive or Negative? National Staff Development Council.

Suparlan, Parsudi. 2002. Tulisan ini merupakan Keynote Address yang disajikan dalam Sesi Pleno I pada Simposium Internasional Jurnal Antropologi Indonesia ke-3: 'Membangun Kembali "Indonesia yang Bhinneka Tunggal Ika": Menuju Masyarakat Multikultural', Universitas Udayana, Denpasar, Bali, 16-19 Juli 2002

Yin, Robert. 2014. Case Study Research: Design and Methods (5th Edition). Thousand Oaks, CA: Sage. 